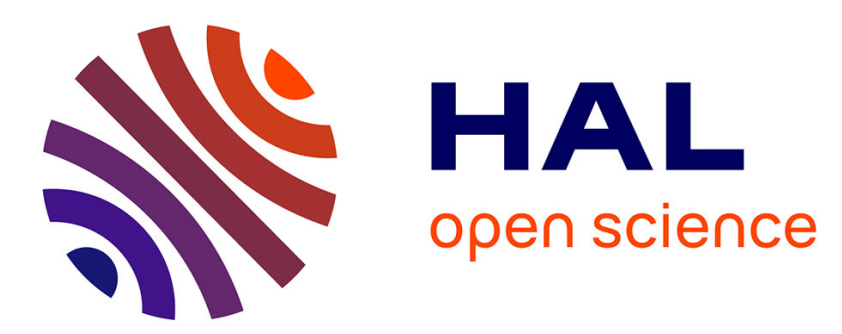

\title{
Evapotranspiration and water relations from a vineyard in central Portugal during spring-summer periods
}

\author{
José Silvestre, Maria Isabel Ferreira, Charles Valancogne
}

\section{To cite this version:}

José Silvestre, Maria Isabel Ferreira, Charles Valancogne. Evapotranspiration and water relations from a vineyard in central Portugal during spring-summer periods. 1. ISHS Workshop, May 1998, Stuttgart, Germany. 10.17660/ActaHortic.1999.493.21 . hal-02770092

\section{HAL Id: hal-02770092 \\ https://hal.inrae.fr/hal-02770092}

Submitted on 4 Jun 2020

HAL is a multi-disciplinary open access archive for the deposit and dissemination of scientific research documents, whether they are published or not. The documents may come from teaching and research institutions in France or abroad, or from public or private research centers.
L'archive ouverte pluridisciplinaire HAL, est destinée au dépôt et à la diffusion de documents scientifiques de niveau recherche, publiés ou non, émanant des établissements d'enseignement et de recherche français ou étrangers, des laboratoires publics ou privés. 


\section{EVAPOTRANSPIRATION AND WATER RELATIONS FROM A VINEYARD IN CENTRAL PORTUGAL DURING SPRING-SUMMER PERIODS.}

\author{
J. Silvestre \\ INIA, Estação Vitivinícola \\ Nacional. \\ Quinta da Almoinha \\ 2560 Dois Portos \\ Portugal
}

\author{
M.I. Ferreira \\ ISA, Universidade Técnica \\ de Lisboa. \\ Tapada da Ajuda \\ 1399 Lisboa \\ Portugal
}

\author{
C. Valancogne \\ INRA, Bioclimatologie, \\ Domaine de la Grande \\ Ferrade. \\ 33883 Villenave-d'Ornon, \\ France
}

Keywords: Vitis vinifera L., water stress, transpiration, eddy correlation, stomatal conductance, leaf water potential.

\section{$\underline{\text { Abstract }}$}

Evapotranspiration (ET), transpiration (T) and some water stress indicators were followed during 96 and 97 . One of the aims was the quantification of the water consumption for subsequent modelling. Another important objective was to improve the understanding of the time evolution of $\mathrm{T}$ during periods of progressively high water deficit, assessing the role of the main controlling factors. $T$ was measured with sap flow techniques and $E T$ with eddy covariance method, during limited periods. Environmental variables and reference evapotranspiration (ETo) were also followed. The relationship between predawn leaf water potential $\left(\psi_{\mathrm{p}}\right)$ and stomatal conductance $\left(\mathrm{g}_{\mathrm{s}}\right)$ at noon, and between those variables and T/ETo are discussed, as well as the seasonal trend of T/ETo. The results show that the relationship ET/ETo ranges between about 0.83 and 0.17 and T/ETo between 0.60 and 0.16 . There is a good relationship between $\psi_{\mathrm{p}}$ and $\mathrm{g}_{\mathrm{s}}$ with a threshold value about $-0.35 \mathrm{MPa}$.

\section{Introduction}

Vineyards are the most important agricultural product in Portugal, representing 7\% of the utilised farm surface and $25 \%$ of the plant gross income. This crop, usually develops with small amounts of rainfall during the main growing season $(30 \mathrm{~mm}$ from June to August, at the region of this experience), leading to a long term soil water deficit. Gas exchanges, growth and maturation can be affected in spite of a natural capacity of survival under these conditions (Champagnol, 1984). In Portugal, the irrigation of vineyards is allowed in the table grape production and in special situations in the wine production. It is necessary to evaluate the water consumption of the crop, either for hydrological purposes, for the characterisation of plant water status and for irrigation scheduling.

This paper describes the evolution with time of evapotranspiration (ET), reference evapotranspiration (ETo) and transpiration (T), during periods of progressively higher water deficit, assessing the role of some main controlling factors. For this purpose, the seasonal course of the ratios T/ETo and ET/ETo are presented and discussed, as well as predawn leaf water potential $\left(\psi_{\mathrm{p}}\right)$ and corresponding midday stomatal conductance $\left(\mathrm{g}_{\mathrm{s}}\right)$. 


\section{Materials and methods}

\subsection{The experimental site}

This study was conducted at Quinta da Amoreira, Tagus valley $\left(39^{\circ} 10^{\prime} \mathrm{N}, 8^{\circ} 43^{\prime} \mathrm{W}\right.$, altitude $5 \mathrm{~m}$ ), during spring and summer of 1996 and 1997. The climate type is humid mesothermic with dry hot summer, mean annual temperature $16.5^{\circ} \mathrm{C}$ and mean annual rainfall $710 \mathrm{~mm}$ (Reis and Gonçalves, 1981). The soil is a deep clay sandy loam with no physical obstacle to root penetration to depth $3-4 \mathrm{~m}$. The water table varies between 1 and $5 \mathrm{~m}$ with the season. The experimental plot was located near the center of an extensive and flat horizontal vineyard $(970 \times 250 \mathrm{~m}$ ), planted in 1984 (Vitis vinifera, cv. 'Trincadeira preta', grafted on SO4). The plant density is 3030 plants ha ${ }^{-1}$. The row direction is NW-SE, perpendicular to the Tagus valley axis. Training is a bilateral cordon with foliage wires at $0.55 \mathrm{~m}, 1.05 \mathrm{~m}$ and $1.45 \mathrm{~m}$ above the soil surface. Leaf area index, measured in August, according Carbonneau (1976 a,b), was 2.39 in 1996 and 1.95 in 1997 (due to more intensive topping and different conditions of these years).

\subsection{Instrumentation and methods}

Air temperature and humidity were measured at $2.84 \mathrm{~m}$ above the soil, using standard ventilated psychrometers. Wind speed was measured at the same height (MCB, Courbevoie, France and A100R Vector Instruments, UK). The wind direction was measured by a potentiometer windvane (W200P, Vector Instruments, UK) at the reference level $(2.84 \mathrm{~m})$. Net radiation was measured at reference level (pyrradiometers $\mathrm{S} 1$ Swissteco, Switzerland and PH. Shenck 8111, Austria). All meteorological sensors were connected to $21 \mathrm{X}$ or CR7 data-loggers (Campbell Scientific, Leicester, UK) which scanned every $10 \mathrm{~s}$ and recorded $20 \mathrm{~min}$ averages (1996) or $30 \mathrm{~min}$ averages (1997).

Latent and sensible heat fluxes were measured using eddy correlation technique. Sonic anemometer with 127 fine wire thermocouple and krypton hygrometer (Campbell Sc. System, USA) were used. Air temperature, vertical wind speed and air humidity were sampled at a rate of $10 \mathrm{~Hz}$ with a flux averaging period of $15 \mathrm{~min}$ and output every 30 min. The eddy fluxes were measured at $3.5 \mathrm{~m}$ and measurements corresponded to a fetch of $600 \mathrm{~m}$. Corrections for temperature effect (Webb et al., 1980) and Krypton $\mathrm{O}_{2}$ absorption effect (Tanner et al., 1993) were made. The data were stored regularly for spectral analysis.

Xylem sap flux was directly measured using a heat balance method adapted from Sakuratani (1981) and Valancogne and Nasr (1993). Stomatal condutance was measured by a steady-state porometer (LI-1600, LI-COR Ltd., Lincoln, NE, USA); the measurements were taken at 4 levels/plant and the average corresponds to, at least, 6 plants. $\psi_{\mathrm{p}}$ was measured by a Scholander pressure chamber; the average corresponds to, at least, 12 plants. ETo was estimated using Penman-Monteith equation with grass parameters: stomatal resistance of $70 \mathrm{~s} \mathrm{~m}^{-1}$ and, for the calculation of aerodynamic resistance, a grass height of $0.12 \mathrm{~m}$ (Allen et al., 1994).

\section{$\underline{\text { 3. Results }}$}

The year of 1996 was characterised by a relatively wet spring, with $158 \mathrm{~mm}$ of rainfall during May (22\% of annual rainfall), and a typical dry and hot summer, with no rainfall until the begining of September (day 249). The second year, 1997, was an atypical year (Fig. 1), with $151 \mathrm{~mm}$ of rainfall between June and August (day 152 to 249). The seasonal 
trend of $\psi_{\mathrm{p}}$ during the two summer periods was clearly different, corresponding to that situation (Fig. 2).

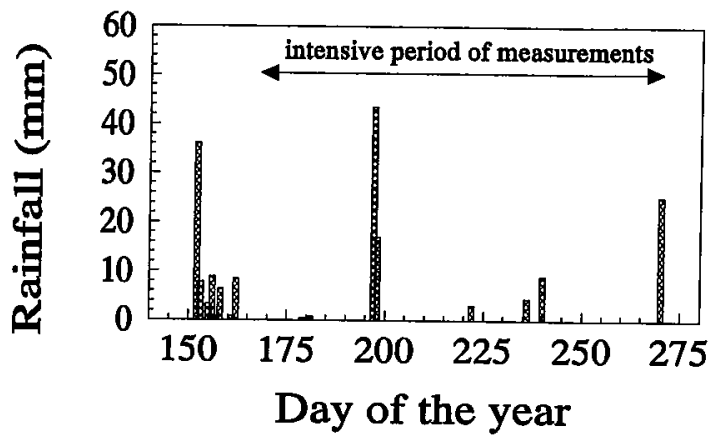

Figure 1. Daily rainfall during Summer 1997 (June-September)

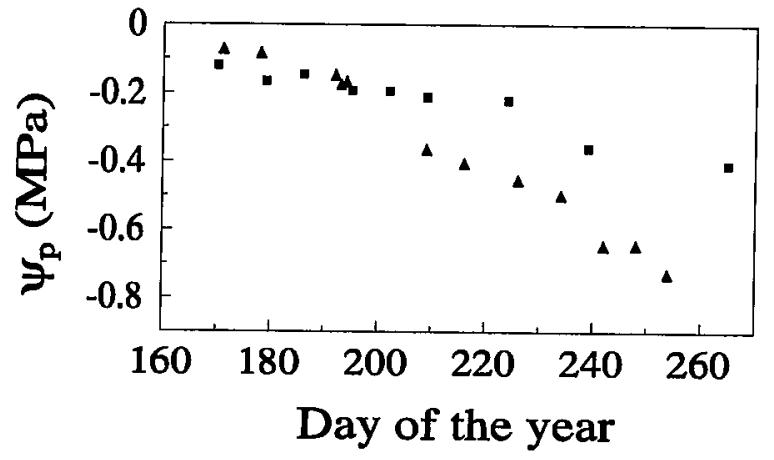

Figure 2. Seasonal courses of predawn leaf water potential. Triangles and squares represent the values for 1996 and 1997, respectively.

Figure 3 shows the seasonal variation on ET, measured by the eddy covariance method (a lack of values from day 172 to 220, during 1997, was due to a technical problem with the krypton hygrometer). In spite of the different meteorological conditions, the values, for both years, were in the same range, except for the days after rainfall (241 and 242).

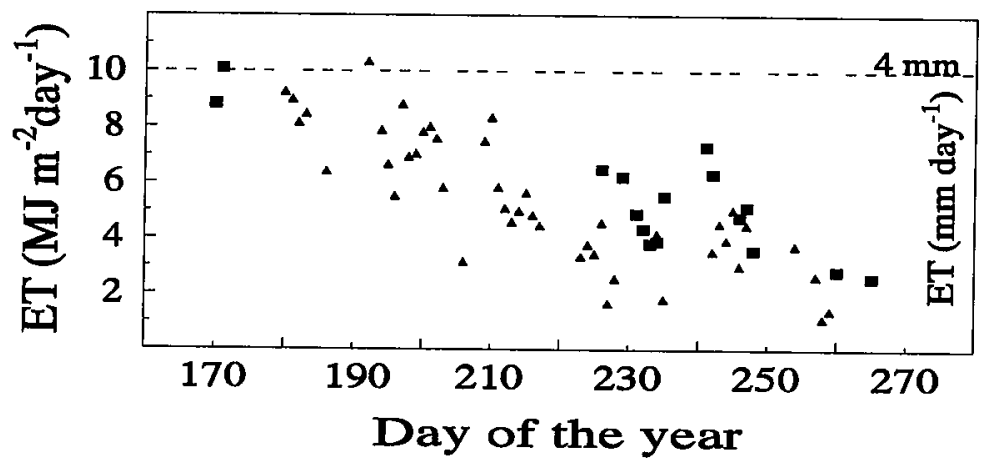

Figure 3. Seasonal courses of evapotranspiration. Triangles and squares represent the values for 1996 and 1997, respectively.

The seasonal variation of the ratio ET/ETo is presented in Figure 4, which also includes the seasonal course of T/ETo for 1997 (Fig 4b). For 1996, the ratio ET/ETo decreases continuously until it stabilises around 0.30. When comparing ET/ETo in 1996 
and 1997, it can be observed that, in 1997, ET/ETo shows a greater instability due to rainfall events during summer (Fig. 1). The ratio ET/ETo also shows higher values in 1997, which represents a situation of moderate water stress when compared to more intensive stress in 1996, as evidenced by the predawn leaf water potential values for both years (Fig. 2).

T/ETo clearly decreased in rainfall days or immediately after (Fig. 4b, Fig. 1).
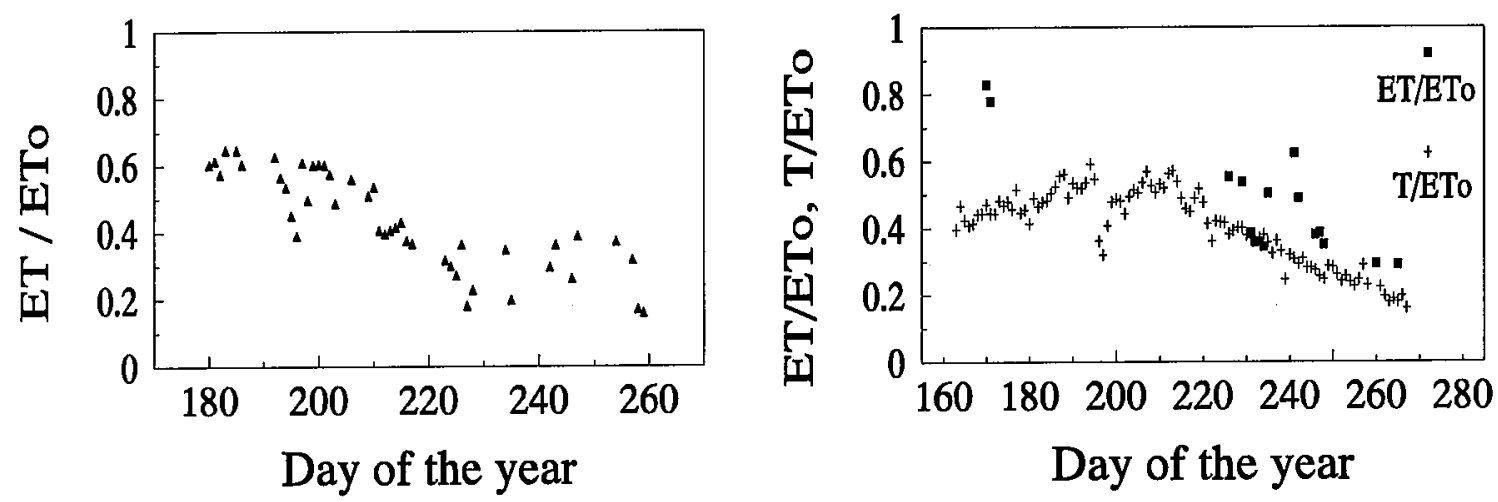

Figure 4. Time course of the ratios (a) ET/ETo, during 1996 and (b) ET/ETo and T/ETo, during 1997.

Figure 5 shows the relationship between $\psi_{\mathrm{p}}$ and midday $\mathrm{g}_{\mathrm{s}}$. Considering all the environmental and physiological variables that influence $\mathrm{g}_{s}$, a reasonable good relationship was found. The results show a continuous decrease of $g_{s}$ with $\psi_{p}$, stronger for values of $\psi_{\mathrm{p}}$ above $-0.35 \mathrm{MPa}$. Below this point, $\mathrm{g}_{\mathrm{s}}$ varies around $0.2 \mathrm{~cm} \mathrm{~s}$ with less scattering than before, decreasing slowly with the $\psi_{\mathrm{p}}$ decrease. A group of points, in the down left side of the figure, is well separated from the global tendency. They correspond to a hot day, with higher values of vapour pressure deficit (VPD) than usually, which induced lower values of $g_{s}$.

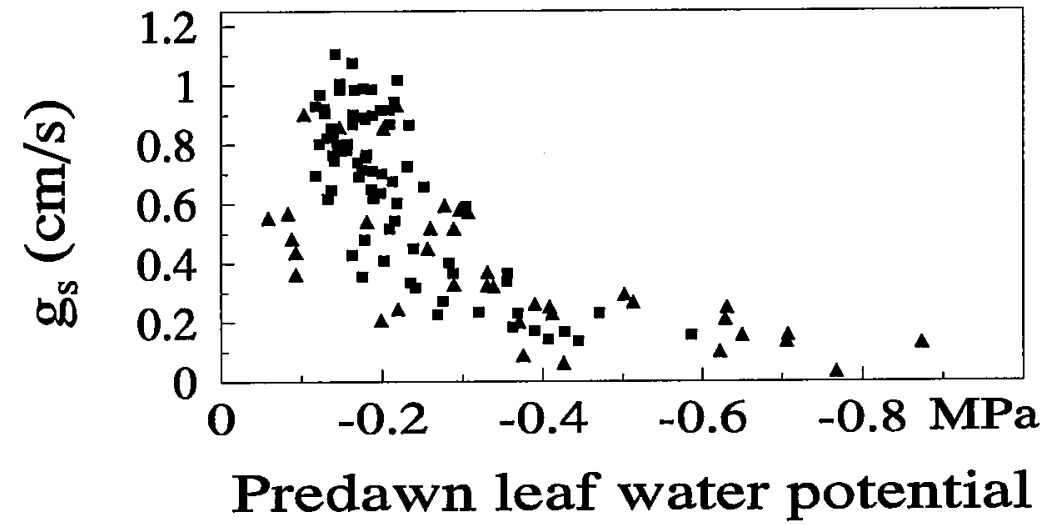

Figure 5. Relationship between midday stomatal conductance and predawn leaf water potential for individual plants, in 1996 (triangles) and 1997 (squares).

Figure 6 shows the relationship between T/ETo and $\psi_{\mathrm{p}}$ or $\mathrm{g}_{\mathrm{s}}$. A great reduction (50\%) in T/ETo is shown for values of $\psi_{p}$ below $-0.35 \mathrm{MPa}$. Above $-0.2 \mathrm{MPa}$, T/ETo doesn't seem to be affected by $\psi_{\mathrm{p}}$. Concerning midday $\mathrm{g}_{\mathrm{s}}$, it can be seen that low values of T/ETo correspond to low values of $g_{s}$, as it would be expected. For midday conductances greater than $0.35 \mathrm{~cm} \mathrm{~s}^{-1}, \mathrm{~T} / \mathrm{ET}$ o shows a very slight variation. 


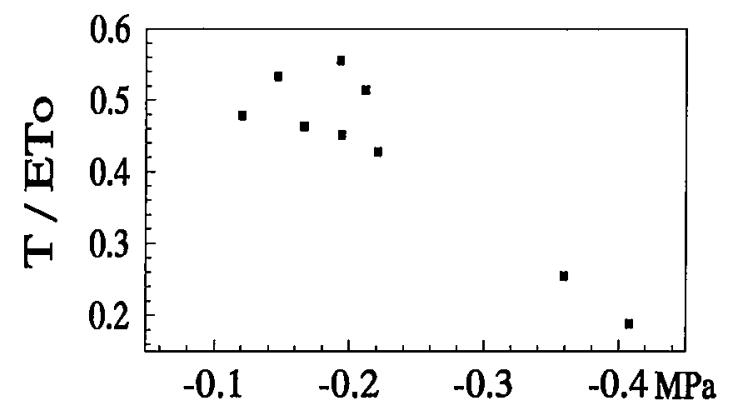

Predawn leaf water potential $\left(\psi_{\mathrm{p}}\right)$

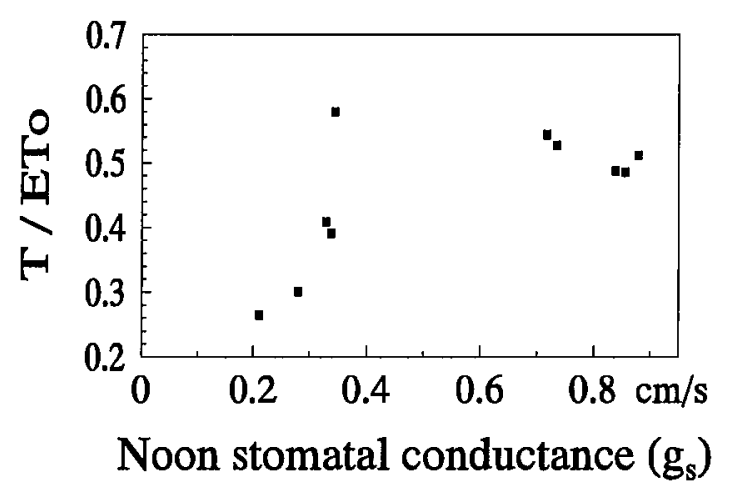

Figure 6. Relation between (a) the ratio T/ETo and predawn leaf water potential and (b) the ratio T/ETo and midday stomatal conductance (average in the plot), during 1997.

\section{Discussion}

These data were obtained in two very different years in what concerns water availability, as it can be seen from Figures 1 and 2. The absence of rainfall during the summer period, led to a progressive decrease of ET/ETo, predawn leaf water potential and midday stomatal conductance, in 1996.

Until the beginning of July 1997 (day 187), T/ETo tends to increase, probably as a result of vegetative growth. After a period of stability, this ratio decreases regularly. This seems to be partially related to senescence, as $\psi_{\mathrm{p}}$ indicates an absence of important water deficit, during that period.

The difference between ET/ETo and T/ETo, at the beginning of the measurements period and immediately after day 241 , shows the contribution of soil evaporation to ET. After day 241, the difference between ET and T decreases continuously showing the decrease in soil evaporation. Similar values were found for ET, obtained with soil water measurements, during 4 years, in the region of Bordeaux, by Rosier et al., (1995): 1.5 to 4 $\mathrm{mm}$, during maturation.

Values of ET are similar for both years. However, ET/ETo is clearly different (Fig. 4), roughly about 0.20 higher in 1997 . During 1996, the higher water stress induced a lower stomatal conductance, reducing ET in relation to ETo. Conversely, the lower driving force, in 1997, was compensated by a higher stomatal conductance, increasing ET/ETo, so that the values for ET/ETo were similar in both years (Fig. 5).

The range of $\psi_{\mathrm{p}}$ obtained is similar to the one found in Portugal (cv 'Fernão Pires'), for the period 1989-1992 (Lopes, 1994), and on cv 'Periquita', in 1993 (Clímaco, 1997). Those authors found that $\psi_{\mathrm{p}}$ varied between -0.2 and $-0.7 \mathrm{MPa}$ or between -0.1 and -1.0 $\mathrm{MPa}$, respectively, both on heavy soils and natural conditions. The values of $g_{s}$ found by the same authors where never higher than about $0.7 \mathrm{~cm} \mathrm{~s}^{-1}$, even if the lowest values found were similar to the ones presented here. It can be observed that the values of $\mathrm{g}_{\mathrm{s}}$ higher than $0.7 \mathrm{~cm} \mathrm{~s}^{-1}$ correspond to 1997 (with VPD values lower than in a typical summer). This fact is an evidence of the well know influence of VPD on $\mathrm{g}_{s}$. Midday conductances of the same range were also obtained by Winkel and Rambal (1990) for cv 'Carignane' and 'Shiraz'.

A good relationship between $\psi_{\mathrm{p}}$ and $\mathrm{g}_{\mathrm{s}}$ was found with an apparent threshold value about -0.35 MPa. The same relationship was found for the cv. 'Periquita' (Climaco 1997). 
However, Correia et al., (1995) found, for cv 'Trincadeira preta', at the same region of this experiment and for 3 levels of water availability (well-watered, moderately stressed and severely stressed) that the decrease on maximum $g_{s}$ was sharper for $\psi_{p}$ values minor than -0.5 MPa. For several stands, such as peach (Ferreira et al., 1996), this relation exhibits a change on slope and scattering for a specific value of $\psi_{\mathrm{p}}$ which can be used as a threshold value for irrigation scheduling.

The relation between T/ETo and $\psi_{\mathrm{p}}$ shows a significant decrease of T/ETo when $\psi_{\mathrm{p}}$ is below $-0.35 \mathrm{MPa}$, which is not contraditory with the threshold value that comes from the interpretation of Figure 5. Also, for values of $\psi_{\mathrm{p}}$ greater than $-0.2 \mathrm{MPa}$, T/ETo doesn't seem to be affected. On the other hand, $\psi_{\mathrm{p}}$ of $-0.35 \mathrm{MPa}$ corresponds to $\mathrm{g}_{\mathrm{s}}$ of about 0.3 $0.35 \mathrm{~cm} \mathrm{~s}^{-1}$ (Fig. 5). This is in agreement with the fact that, in Figure $6 \mathrm{~b}$, the change in $\mathrm{T} / \mathrm{ET}$ corresponds to $0.35 \mathrm{~cm} \mathrm{~s}^{-1}$ for $\mathrm{g}_{\mathrm{s}}$. It is also not very different from data obtained by Nagarajah (1989), who referes -0.2 to $-0.3 \mathrm{MPa}$ as a threshold for non-stressed grapevines.

\section{Acknowledgements}

The work presented was supported by the project PEAM/C/GRH/587/95 (FCT, exJNICT, Portugal). It also received a contribution from PAMAF 2056 (Min. of Agriculture, Portugal), ICCTI (Portugal), French Embassy in Lisbon and French Ministère de 1'Education Nationale de la Recherche et de la Technologie (trainingresearch net). The authors acknowledge Mrs. Sylvia Dayau for collaboration and Prof. Lopes Aleixo for field facilities.

\section{$\underline{\text { References }}$}

Allen R.G., Smith M., Pereira L.S. and Perrier A., 1994. An update for the calculation of reference evapotranspiration. ICID bulletin 43 (2): 1 - 34 .

Carbonneau A., 1976 (a). Principes et méthodes de mesure de la surface foliaire. Essai de caractérisation des types de feuilles dans le genre Vitis. Ann. Amélior. Plantes, 26 (2): $327-343$.

Carbonneau A., 1976 (b). Analyse de la croissance des feuilles du sarment de vigne: estimation de sa surface foliaire par échantillonnnage. Connaissance de la Vigne et $\mathrm{du}$ Vin, $10(2): 141$ - 159.

Champagnol F., 1984. Elements de physiologie de la vigne et de viticulture general. Ed. Auteur, Montpellier, $354 \mathrm{pp}$.

Clímaco P., 1997. Influência da cultivar e do ambiente na maturação da uva e na produtividade da videira (Vitis vinifera, L.), $121 \mathrm{pp}$., Ph. D. Thesis, Instituto Superior de Agronomia, Lisboa.

Correia M.J., Pereira J.S., Chaves M.M., Rodrigues M.L. and Pacheco C.A., 1995. ABA xylem concentrations determine maximum daily leaf conductance of field-grown Vitis vinifera L. plants. Plant. Cell and Environment 18: 511 - 521.

Ferreira M.I., Valancogne C., Daudet F-A., Ameglio T., Michaelsen J. and Pacheco C.A., 1996. Evapotranspiration and crop water relations in a peach orchard. In: Evapotranspiration and Irrigation Scheduling. Proceed. of Int. Conf. Nov. 3-6. San Antonio, Texas (US), ASEA: 61 - 68.

Lopes C. 1994. Influência do sistema de condução no microclima do coberto, vigor e produtividade da videira (Vitis vinifera L.), 205pp., Ph. D. Thesis, Instituto Superior de Agronomia, Lisboa. 
Nagarajah S. 1989. Physiological responses of grapevines to water stress. Acta Horticulturae, 240: 249 - 256.

Reis R. and Gonçalves M., 1981. O Clima de Portugal, Fascículo XXXII. Caracterização climática da região agrícola do Ribatejo e Oeste. INMG, Lisboa.

Rosier J.P., Carbonneau A. and Seguin G., 1995. Consumo hídrico da videira em função do tipo de solo e do sistema de condução. Pesq. Agropec. Bras., 30 (6): 819 - 824.

Sakuratani T., 1981. A heat balance method for measuring water flow in the stem of intact plant. J. Agric. Meteorol., 37: 9 - 17

Tanner B.D., Swiatek E. and Greene J.P., 1993. Density fluctuations and use of krypton hygrometer in surface flux measurements. Proceedings of the 1993 Nat. Conf. on Irrig. and Drainage Engineering, Irrig. and Drain. Division, ASCE.

Valancogne C. and Nasr Z., 1993. A heat balance method for measuring sap flow in small trees. in Water Transport in Plants under Climatic Stress, Proceeding of a International Workshop ,held in Vallombrosa, Firenze, (Italy), 29-31 may 1990, (ed. Borghetti M., Grace J. and Raschi A.), Cambridge University Press, Cambridge, 166 173.

Webb E.K., Pearman G.I. and Leuning R., 1980. Correction of flux measurements for density effects due to heat and water vapour transfer. Quart. J. Royal Met. Soc. 106: 85 $-100$.

Winkel T. and Rambal S., 1990. Stomatal conductance of some grapevines growing in the field under Mediterranean environment. Agric. For. Meteor. 51: 107 - 121. 